TABLE $\dagger$ (continued)

Status of the Chemical Sterilant Products Tested in the EPA antimicrobial Efficacy Testing

Program, February 1995

\begin{tabular}{lll}
\hline Product Name & Test Results & status \\
\hline Alcide Exspor (45631-3) & Failed & $\begin{array}{c}\text { Restricted use to veterinary and animal research sites. Currently on the } \\
\text { market. } \\
\text { Restricted use to veterinary and animal research sites. Currently on the } \\
\text { market. }\end{array}$ \\
$\begin{array}{lll}\text { Wavicide-01 (151361) } & \text { Failed } & \text { Failed } \\
\text { Wavicide-01 Concentrate (151362) } & \text { Failed } & \text { Enforcement action pending. Products remain on the market. }\end{array}$
\end{tabular}

- EPA has allowed this failed sterilant back on the market because the registrant has reformulated the product, changed the use directions (time and temperature required for sterilization), increased the percentage of active ingredient, and retested the product. New data have been submitted to EPA by the registrant showing that the product is effective according to the new label. EPA carefully reviewed the new data and determined that the product is effective as stated on the label. † From reference 2 .

gan M. Effect of HIV infection and tuberculosis on hospitalizations and cost of care for young adults in the United States, 1985 to 1990. Ann Intern M ed 1994;121:786-792.

\section{Remarkable Discovery Has Implications for HIV Treatment}

Until recently, HIV infection has been thought of as a gradual process in which the virus slowly invades the immune system. Findings from two recently published studies report that the virus and the immune system engage in a battle from the very beginning of infection.

Each day, millions of new HIV virus particles are produced and killed. But the immune system's losses also are staggering, with up to 1 billion infected T cells dying and being replaced each day. This battle continues with the immune system losing ground each day. These findings were reported in two independent studies by two leading AIDS researchers, Dr. David Ho, director of the Aaron Diamond AIDS Research Center in New York, and Dr. George Shaw, University of Alabama in Birmingham.

The major discovery is that the half-lie of the circulating virus and the cells producing the virus is only 2 days-not weeks or months, as previously thought. However, within 2 to 4 weeks, a new and drug-resistant strain of the virus takes over. One of the key factors behind the new findings was new drugs that stop the activity of HIV-enabling researchers to measure how fast the virus population declines and recovers. Dr. Shaw and his team studied 22 patients given three new drugs that block the activity of two viral enzymes required for viral replication. One drug, nevirapine (NVP), inhibits reverse transcriptase. The others, ABT-538 and L-735,524, inhibit the protein-cleaving enzyme the virus uses to manufacture protein coats for new virus particles. In the New York study, Dr. Ho and his team had similar results with the use of ABT-538 on 20 patients.

The two teams found that within two weeks, all the virus in a patient's body was resistant and that between 100 million and 1 billion new viruses were being produced each day. The continuous production of large amounts of infective viruses drives the rapid turnover of the immune system's susceptible T cells.

However, the investigators noticed that when they halted virus production with a drug, the immune system worked full throttle to produce new T cells, approximately 1 billion per day. It is believed that the HIV virus gradually gains ground, killing a few more $\mathrm{T}$ cells each day than are being replaced, causing a noticeable decline in $\mathrm{T}$ cells over time.

This new picture of HIV infection, the researchers note, suggests new strategies for dealing with the virus. The baffle between the immune system and the virus is so close that any drug that weakens the virus and gives the immune system an edge might be enough to tip the balance.

FROM Ho DD, Neumann AU, Perelson AS, et al. Rapid turnover of plasma virions and CD4 lymphocytes in HIV-1 infection. N ature 1995;373(6510):123-126. Wei X, Ghosh SK, Taylor ME, et al. Viral dynamics in human imnmnodeficiency virus type 1 infection. N ature 1995;373(6510):117-122. Kolata, G. New AIDS findings on why drugs fail. New York Times January 12, 1995. 


\section{Stiti}

\section{The Society for Healthcare Epidemiology of America}

\section{SHEA/CDC/AHA}

\section{Training Course in Hospital Epidemiology}

\section{Program}

The program will be held May 6-9, 1995 at the Hyatt Regency Embarcadero, San Francisco, California. Timothy W. Lane, M.D., William Martone, M.D., and Gina Pugliese, R.N., MS., will co-chair the program.

\section{Purpose}

This program, developed by the Society for Healthcare Epidemiology of America (SHEA), the Centers for Disease Control and Prevention (CDC), and the American Hospital Association (AHA), is intended for infectious disease fellows and new hospital epidemiologists. It emphasizes hands-on exercises in which participants work in small groups to detect, investigate, and control epidemiological problems encountered in the hospital setting. These work sessions are supplemented with lectures and seminars covering fundamental aspects of hospital epidemiology including epidemiology and surveillance, epidemic investigation, transmission and control of nosocomial infections, disinfection and sterilization, employee health, isolation systems, regulatory compliance, and quality improvement.

\section{Who Should Attend}

You should attend if you are a hospital epidemiologist or an infection control practitioner or if you are looking for a course that will provide you the most current information concerning infection control practices and epidemiological methods in health care. This fundamental program will provide you with the opportunities to find solutions to real situations that will occur in the hospital setting. Intensive problem solving sessions are supplemented with lectures and seminars presented by leading authorities.

\section{Scholarships}

Scholarships in the amount of $\$ 1,000$ will be awarded to up to ten infectious disease fellows for the program to defray the special course fee for fellows of $\$ 350$ and expenses incurred in attending the training program.

Interested fellows must submit a letter of no more than one page describing why they would like to have additional training in hospital epidemiology, A letter from the fellow's program director outlining the applicant's qualifications and suitability for the course also is required. The deadline for receipt of scholarship applications for the course is Wednesday, March 15, 1995
The SHEA Educational Activities Committee will select the scholarship recipients based on review of these letters. Winners will be notified in late March, 1995.

\section{Nominations}

Please send scholarship applications to:

Timothy A. Lane, M.D.

c/o The Society for Healthcare Epidemiology of America

875 Kings Highway, Suite 200

Woodbury, NJ 08096-3172

Fees

Individual Registrants \$495

Fellows in Infectious Disease $\$ 350$

\section{Credits}

The Centers for Disease Control and Prevention (CDC) is accredited by the Accreditation Council for Continuing Medical Education to sponsor continuing medical education for physicians.

The Centers for Disease Control and Prevention designates this continuing education activity for up to 21 hours in Category 1 of the Physician's Recognition Award of the American Medical Association.

\section{General Course Information}

Information regarding the schedule, hotel and travel accommodations, discount airfare, and course fees are available from SHEA (609) 845-1720. Note that application for a scholarship does not constitute enrollment in the program. This must be done separately.

Scholarship Awards provided in part by an educational grant from SmithKline Beecham

\section{SB \\ SmithKline Beecham \\ Pharmaceuticals}

